\title{
Isolation and identification of a native microbial consortium for the coffee pulp degradation above 2000 masl
}

\author{
Marcela N. Arteaga Cuba1 (iD, Josué O. Dilas-Jiménez² (D), Norberto Villanueva Díaz ${ }^{3}$ D, Ofelia C. Cernaqué Miranda ${ }^{4}$, \\ Segundo M. Tafur Santillán ${ }^{1}$ (D), José Enrique Olivera García ${ }^{5}$ (D) Carlos A. Mugruza-Vassallo ${ }^{6}$ iD
}

${ }^{1}$ Universidad Nacional de Cajamarca/UNC, Jaén, Cajamarca, Perú

${ }^{2}$ Universidad Nacional Autónoma de Tayacaja Daniel Hernández Morillo/UNAT, Pampas, Huancavelica, Perú

${ }^{3}$ Najy Consulting \& Business S.A.C./NAJY SAC, Jaén, Cajamarca, Perú

${ }^{4}$ Universidad Peruana de Ciencias Aplicadas/UPC, Lima, Lima, Perú

${ }^{5}$ Universidad Nacional Mayor de San Marcos/UNMSM, Lima, Lima, Perú

${ }^{6}$ Universidad Nacional Tecnológica de Lima Sur/UNTELS, Grupo de Investigación en Computación y Neurociencia Cognitiva, Lima, Lima, Perú

Contact authors: arteagacuba@gmail.com, josuedilas@gmail.com, norvil10@gmail.com, ccernaque@gmail.com, stafur@unc.edu.pe, joliverag@unmsm.edu.pe, cmugruza@yahoo.com Received in August 28, 2020 and approved in June 16, 2021

\begin{abstract}
Pulp and mucilage constitute the most abundant by-products of the processing of coffee and inadequate handling produces high-rates of pollution. Considering that in nature there is a large variety of cellulolytic microorganisms which can intervene in the degradation of coffee pulp, the inclusion of a native microbial cellulolytic consortium was assessed. The sample for isolation consisted of coffee pulp and soil from a humid forest at more than 2,000 masl. Nutrient agar was used as a means of isolation for bacteria, and malt agar for fungi, supplemented with $50 \%$ soil extract and $1 \%$ carboxylmethylbcellulose. This achieved the isolation of 118 strains of bacteria and 114 of fungi. Cellulolytic activity was established using the filter paper test, assessing and selecting only those that presented higher glucose production, among them 12 strains of fungi and 11 strains of bacteria. To obtain the microbial consortium, randomized blends were performed for both fungi and bacteria, again assessing the production of glucose. The bacterial consortium was made up of Ochrobactrum pseudo grignonense, Paenibacillus lauruscon and Bacillus xiamenensis and the fungal consortium by Fusarium sp., Penicillum sp., Cylindrocarpon sp. The optimal treatment achieved a complete degradation of the pulp in 28 days, that would contribute to the recovery and conservation of the coffee ecosystem. The main interpretation was that a wet environment at more than 2,000 masl is still suitable for coffee composting but different bacterial and fungi consortia were found to support other recent work done with one type of consortium.
\end{abstract}

Key words: Carboxymethylcellulose (CMC); Cellulose; Coffee pulp; Degradation; Microbial consortium; Meters above sea level (masl).

\section{INTRODUCTION}

Coffee pulp represents around $42 \%$ of fresh fruit weight, being the most voluminous by-product of the humid beneficiary. Every two tons of coffee produces approximately a ton of pulp; therefore, it is important to minimize the risks and environmental impact from its mishandling Duangjai et al. (2016). The high volume of pulp can be an environmental problem, taking into account that in many cases, it is poured into bodies of water, so that the microorganisms present will make a greater demand for oxygen for decomposition and thus lead to asphyxiation of the aquatic biota Serna-Jiménez et al. (2018). The pulp represents a pollutant load equivalent to 20 kilograms of chemical oxygen demand (COD) per $100 \mathrm{~kg}$ of gold coffee Didanna (2014) which is an annual population equivalent of 0.96 per person, while the mucilage, liquid residue, represents between 5\% and $14 \%$ of the weight of the fruit, e.g. Bressani (1978), Didanna (2014). Further studies found that the pulp has almost triple the contaminant load compared to the mucilage Zambrano-Franco and IsazaHinestroza (1998) and Geremu, Tola and Sualeh (2016) say that coffee pulp is highly polluting and toxic to its concentration of caffeine, mineral salts, amino acids, tannins, phenols and other polyphenols. Finally, only $9.5 \%$ of the weight of the fruit is used to prepare the infusion of Arabic coffee (Calle-Velez, 1977).
Considering that several studies have been carried out for decades to take advantage of coffee waste and by-products, this study focuses on the decomposition of pulp.

The pulp is rich in organic matter and is an ideal substrate for the microbiological process. Coffee pulp fertilizer is preferably used to establish new coffee plantations and for nurseries, mainly the pulp of ripe coffee that have higher mineral content (Velasquez et al., 2021). Vásquez de Diaz and colleagues have indicated that the process of degradation of coffee pulp under natural conditions without handling, normally takes 5 to 9 months, time to reach the degree of maturity to perform biotransformation, mineralization or complete degradation of the coffee pulp (Vásquez de Díaz; Prada; Mondragon, 2010), similar to the time on other organic remains such as tree pruning Heck et al. (2013). On the other hand, on a sewage sludge compost around 3 month tales to have a total organic carbon around nine times total nitrogen at around 650 masl (Diniz et al., 2016).

Zaldivar and colleagues found that protein content and release of reducing sugars on filter paper permitted an estimation of the growth dynamics and metabolism of each fungus (Zaldívar et al., 2001), reviewed later by (Shokrkar, Ebrahimi, Zamani, 2018). Based on fungal growth, a considerable fraction of the extracellular protein present in the 
culture medium corresponded to the enzymes that carry out the degradation of the substrate, in this case the cellulase complex. In some fungi the enzyme complex is deficient in the amount or activity of any of the three types of enzyme, which causes poor cellulose hydrolysis. Mantilla and Pineda carried out work on the isolation of cellulolytic bacteria from termite intestines (Nasutitermes nigriceps) with prebiotic characteristics in grass degradation using carboxymethyl cellulose (CMC) obtained that the production of reducing sugars. They observed that the BTN6 and BTN8 bacteria presented a similar trend. Following an increase in the concentration of these sugars in the first 48 hours, the BTN8 bacteria was more efficient with a subsequent decrease in these concentrations at 72 hours of incubation Mantilla and Pineda (2013). The aforementioned authors also demonstrated the importance of soil microorganisms for organic degradation, because it has a diversity of properties in their great microbial richness. However, some available studies were found on the characterization of the microbiota present in them that were useful in the process of optimal degradation of tons of waste such as those generated by the post-harvest processing of coffee and in particular coffee pulp.

The identification of microorganisms that accelerate the composting process would help coffee farms to advance the decomposition in less than 90 days using coffee by-products in the production of organic fertilizer according to Technical Standards in Colombia (Instituto Colombiano de Normas Tecnicas y Certificacion - INCOTEC, 2004). For fungal degradation of the pulp, the first reports pointed at Penicilllium sp. (Schwimmer; Kurtzman; Heftmann, 1971), Aspergillus sp. (Mazzafera, 2002) and also found systematically at a lower rate Cylindrocarpon sp. (Alvindia; Acda, 2013) and also for Fusarium sp. (Nayak et al., 2013).

However, a recent study of fungal contamination found 97.57\% associated with Aspergillus sp. and Penicillium sp. (Viegas et al., 2017). Therefore, some authors have explored the acceleration of pulp decomposition, e.g. Sánchez and colleagues with nitrogen in 28 days with different species of earthworm Sánchez, Olguin and Mercado (1999), Raphael and Velmourougane with Eudrilus eugeniae and Perionyx ceylanesis in a time period of 112 days and 165 days, respectively Raphael and Velmourougane (2012).

In contrast, there has recently been increased research using several bacterial strains for cellulose degradation. For example, Paenibacillus sp. were found as part of a growing microbial consortium in a mixed residue of diesel and chromium sludge Vrdoljak et al. (2005) and also has seen a strain useful in cellulose degradation Wang et al. (2008) and recently the Bacillus sps. was found on enzyme production capacity mainly in amylase nitrate reductase cellulase, xylanase and protease, which were studied for the degradation of sugar in cellulose but not in coffee Utekar and Deshmukh (2019).
Moreover, most of the research was done below 2,000 masl (e.g. bacteria and yeast at two altitude França, et al. (2016) and season response in bacteria Siles and Margesin (2017). Some recent research has looked at consortia across different masl (e.g. bacteria Siles; Margesin, 2016).

Therefore, the present research focused on fungi and bacteria consortia above 2,000masl to gain further insight compared to the few previous studies on microbial consortia studies. This research aimed at identifying soil microorganisms with cellulose degradation capacity and groups them in an optimal microbial consortium for the degradation of coffee pulp at 2,300 masl.

\section{MATERIAL AND METHODS}

\subsection{Soil Sampling}

Sampling activity occurred in the jurisdiction of San Luis del Nuevo Retiro, Cajamarca, Perú (Coordinates UTM 728126 E, 9373449 N, approximately 2300 masl) which is a cloud forest. A simple sample was made, in which a volume of wet soil $(\sim 0,500 \mathrm{~kg})$ was obtained at a depth of $0.00-0.10$ $\mathrm{m}$ with a sterile shovel and stored in a black polyethylene bag (Nasco Whirl-Pak) and taken to the laboratory and stored in refrigeration $\left(3.3\right.$ to $\left.5^{\circ} \mathrm{C}\right)$. Only $0.010 \mathrm{~kg}$ from sampling was used to make the dilutions for isolation. The sample was collected on May 2013.

\subsection{Sampling coffee pulp residue}

Coffee pulp was extracted from the wet benefit of coffee plantations located in the center of La Lima, La Coipa district, San Ignacio province, Cajamarca region in Peru. $20 \mathrm{~kg}$ of one-week old Catimor coffee pulp was extracted.

\subsection{Primary isolation of cellulose degrading microorganisms}

In the process of primary isolation of fungi and soil bacteria, 6 different solid culture media were prepared at $\mathrm{pH}$ 6.0 for bacteria, and $\mathrm{pH} 5.0$ for fungi replacing glucose with $\mathrm{CMC}$ as the only source of carbon. Culture media were: V8 agar medium (Moros et al., 2009) containing $0.500 \mathrm{~L}$ of $\mathrm{V} 8$ juice, $0.020 \mathrm{~kg} \mathrm{CMC}, 0.020 \mathrm{~kg}$ of agar and $0.500 \mathrm{~L}$ of soil extract; half potato dextrose agar (PDA) containing $0.200 \mathrm{~kg}$ of PDA agar, $0.020 \mathrm{~kg}$ of $\mathrm{CMC}$ and $0.500 \mathrm{~L}$ of soil extract; malt agar medium, containing $0.020 \mathrm{~kg}$ of malt extract agar, $0.020 \mathrm{~kg}$ of CMC and $0.500 \mathrm{~L}$ of soil extract; salt base agar medium, containing $0.003 \mathrm{~kg} \mathrm{~L}$ of yeast agar-extract, 0.020 $\mathrm{kg} \mathrm{CMC}$ and $0.500 \mathrm{~L}$ of soil extract; cellulose agar medium, containing $0.020 \mathrm{~kg}$ of agar, $0.020 \mathrm{~kg}$ of CMC and $0.500 \mathrm{~L}$ of soil extract, and nutritive agar used only for bacterial growth. In the fungal growth media, $10-5 \mathrm{~kg} \mathrm{~L}^{-1}$ of streptomycin was also added. Further results are summarized in Figure 1. 

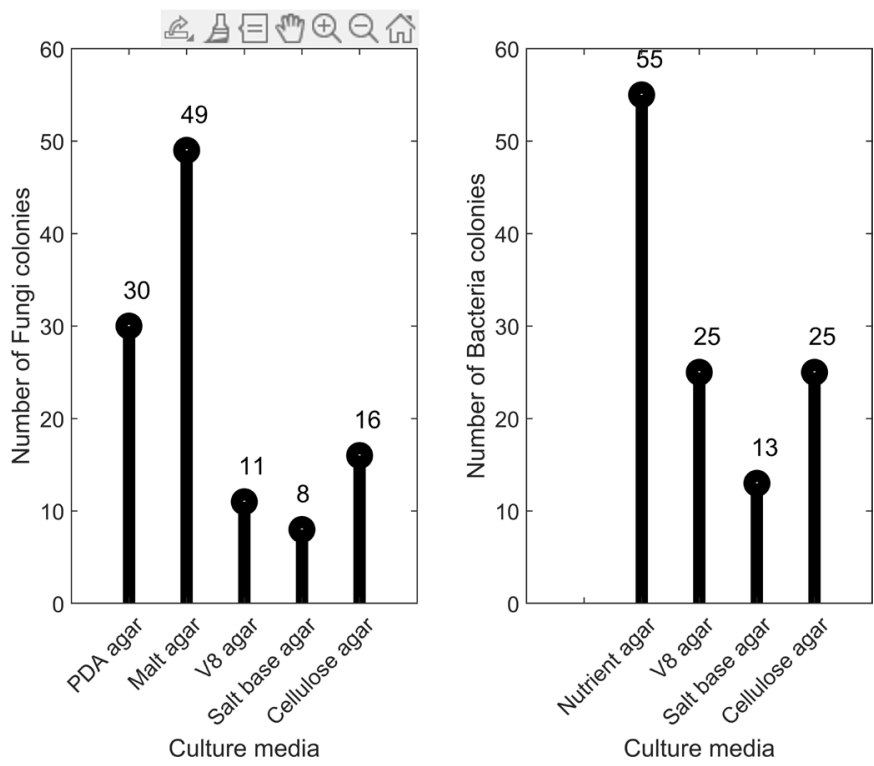

Figure 1: Number of colonies by culture. Left: of fungi. Right: of bacteria.

For soil extract preparation, , $0.4534 \mathrm{~kg}$ of soil with 1 liter of water were kept under stirring for 48 hours, filtered with several layers of gauze and carried at a volume of 1 liter with water, $\mathrm{KH}_{2} \mathrm{PO}_{4}$ was subsequently added and finally autoclaved.

For sowing, $0.010 \mathrm{~kg}$ of soil was diluted in $0.100 \mathrm{~L}$ of sterile distilled water, making dilutions up to $10^{-7}$ and $0.0001 \mathrm{~L}$ of diluted soil. This was then disseminated on the medium using a sterile Drigalski handle and incubating the plates at room temperature. Observations occurred at 24, 48 and 72 hours.

Following the growth period, colonies of bacteria and fungi were transferred to test tubes with a solid medium containing peptone agar (for bacteria) or malt agar (for fungi) plus soil extract and $1 \% \mathrm{CMC}$ as the only source of carbon. Tubes were incubated at $25{ }^{\circ} \mathrm{C}$ and those that grew were selected. For the selection of fungi, 1\% congo red was applied disseminating the dye on the surface (Sazci; Erenler; Radford, 1986). Only those that formed yellowish halos were selected Kasana et al. (2008) and more recently in Sajith et al. (2014).

\subsection{Compatibility test and cellulolytic capacity of consortia}

The strains with the highest glucose production were selected to be confronted to determine their antagonism, using the direct dual confrontation test (Barbosa; Meza, 2009; ParraGonzález et al., 2009).

Later, there were measured the presence or absence of the inhibition halo being positive those that did not show halo of inhibition. For the tests, in the case of bacteria they were plated on peptone agar plates and for fungi on malt agar plates.
The selected consortium groups were then evaluated for their overall cellulolytic capacity, by sowing each combination in $20 \mathrm{~mL}$ of peptonized broth as indicated above.

\subsection{Preparation of inoculum for degradation of coffee pulp at laboratory level}

The cellulolytic activity of the strains of bacteria and fungi selected were tested in one week old catimor coffee pulp. For inoculum preparation, strains of each consortium were sown in nutritive agar (bacteria) and in malt agar (fungi), supplemented in both cases with $1 \% \mathrm{CMC}$. Then, $3 \mathrm{~kg}$ of coffee pulp was placed in four tanks, two of which were to first inoculate the bacteria and left for 7 days. After this time the fungi were inoculated. In the other two deposits, both fungi and bacteria were inoculated simultaneously. As a control, one deposit of only coffee pulp was placed.

The inoculum was prepared by diluting the strains in chopped broth and then $0.010 \mathrm{~L}$ was inoculated into each sample observing the deposits daily.

\subsection{Morphological characterization of the selected microorganisms}

Morphological and molecular characterization of the selected microorganisms was carried out in the laboratories of the Universidad Nacional Agraria La Molina in Lima, Perú.

For the identification of fungi in Petri dishes, colonies were seeded containing the PDA culture media, V-8 agar and incubated at $24{ }^{\circ} \mathrm{C}$ for 5 to 8 days, with microscopic identification from the spores formed and then, a staining was done Gram staining was performed to observe cell morphology and bacterial identification.

\subsection{Molecular characterization of the selected microorganisms}

For this, genomic DNA was isolated and its 16s rRNA gene was amplified using a universal primer in a Master cycle $^{\circledR}$ thermal cycler. The programs followed were initial denaturation of the DNA strands at $94{ }^{\circ} \mathrm{C}$ for 2 minutes, annealed with primers at $55{ }^{\circ} \mathrm{C}$ for 1 minute and extended for 10 minutes at $72{ }^{\circ} \mathrm{C}$. Approximately $1500 \mathrm{bp}$ of the PCR product was purified to remove dNTPS and unincorporated primers prior to sequencing using the PCR purification kit (Quiagen).

In the $16 \mathrm{~s}$ rDNA gene sequencing analyzes, amplified chains were sequenced by a DNA sequencer -3037xl DNA analyzer using the BigDye ${ }^{\circledR}$ terminator v3.1 cycle sequencing kit. The aligned sequences were converted to dendograms using the sequence analysis software version 5.2. These sequences were compared with the sequences in the NCBI database using BLASTN. The most similar sequences were matched by E core and aligned by CLUSTAL W2 for multiple alignments. Finally, the phylogram was constructed using the MEGA5 software. 
Regarding the $8 \mathrm{~B}$ consortium bacteria were identified by comparative analysis with 16s Ribosomal gene sequences, deposited in the Gen Bank, Paenibacillus lautus and Bacillus Xiamenensis. This consortium has been used with other types of substrates, such as garden litter with the aim of obtaining a type of alcohol, or using household organic waste to use them as a bio-fertilizer, achieving complete degradation in 5 days.

\subsection{Statistical analysis}

Frequency tables were designed in Ms. Excel version 2010 and statistical analysis of variance (ANOVA) with Matlabanoval and anovan commands were used to compare isolation of cellulose degrading microorganisms and cellulolytic capacity of compatible consortia. The BLASTN program was used for molecular identification.

\section{RESULTS}

\subsection{Isolation of cellulose degrading microorga-} nisms

Selection of cellulolytic microorganisms was determined by visual inspection of hydrolysis halos. Ramírez and Coha found that dilution allowed the generation of separate colonies, and each colony can come from a single cell or from a cluster (viable unit) which will be counted as a bacterium P. (Ramírez; Coha, 2013). On this basis, these plates were not only used for counting microbial populations but also for the isolation of organisms. A selective or nonselective medium can be used depending on the nature of the microorganisms to be isolated.

In the present research, for dilution of fungi, from which a better result was obtained than utilizing PDA agar, as observed in Figure 2. Bearing in mind the significant ANOVA results $(\mathrm{p}>0.0021 @ \mathrm{~F}=3.056)$, the Malta Agar medium supplemented with $1 \%$ CMC obtained the best isolation of cellulolytic fungi.
For the isolation of bacteria, culture media were supplemented with $1 \% \mathrm{CMC}$ at $\mathrm{pH} 6$. Regarding the media used the modified nutrient agar revealed the highest growth of bacterial colonies.

Figure 1 has shown the primary isolation of fungal colonies (left part) and bacteria (right part) developed in the laboratory. In total, 118 colonies of bacteria and 114 colonies of cellulose degrading fungi were obtained.

From 114 colonies of fungi planted in medium with $1 \%$ CMC, 81 colonies formed yellowish halos (Figure 2).

\subsection{Cellulolytic capacity of bacterial and fungi isolated}

In a second selection of bacteria and fungi with cellulolytic activity, each strain was activated in the presence of filter paper as the carbon source. 19 strains of bacteria and 21 fungi were selected (Table 1 and 2), observing greater action lithic in fungal exudate (up to $57.39 \%$ ) with respect to bacterial exudate (10.41\%). This result was directly proportional to the presence of glucose evaluated in the medium, the presence of glucose in the fungi being greater. Of the 19 strains of fungi isolated, strain $\mathrm{H} 15$ and $\mathrm{H} 26$ showed high cellulolytic activity which makes them excellent biological candidates for composting. Among the colonies of selected bacteria, strains B26 and B38 showed great potential.

Regarding bacterial and fungal strains selection with greater cellulolytic activity Tables 1 and 2 have shown the strains of bacteria and fungi degraded by filter paper (Watman No. 1) to glucose, selecting 21 colonies from the initial 68 at the beginning. The percentage of degradation of filter paper was also observed: strain B16 with higher degradation (10.41\%), and strain B20 with a lower degradation percentage. In fungi, 19 strains of a total of 81 were selected. Table 2 reveals that the $\mathrm{H} 26$ strain exhibited the highest degradation percentage (57.39\%) and the H222 strain the lowest degradation (0.04\%).

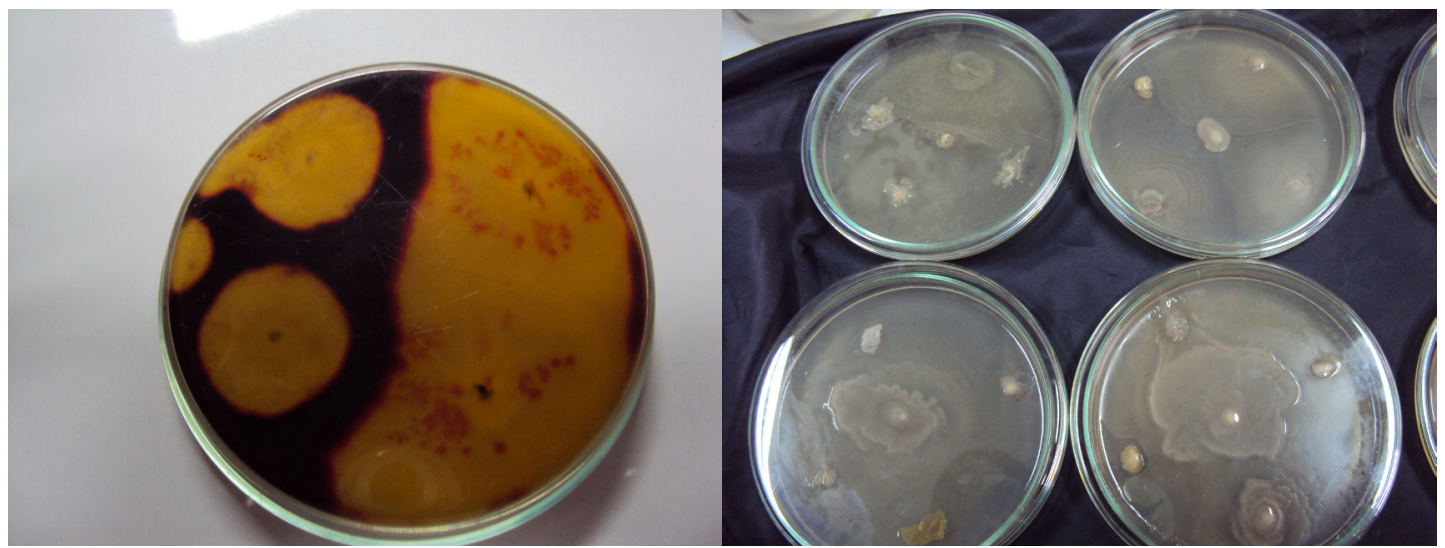

Figure 2: A: Fungal growth and the Congo red test where the yellowish halo is shown. BA: Growth of bacteria in medium having the only $1 \%$ carboxymethylcellulose carbon source. 
Table 1: Glucose production by strains of selected bacteria $\left({ }^{*} 10^{-6} \mathrm{~kg} \mathrm{dL}^{-1}\right)$.

\begin{tabular}{|c|c|c|c|c|c|c|}
\hline No & Wight paper $\left(* 10^{-6} \mathrm{~kg}\right)$ & Strain & $\begin{array}{c}\text { Glucose } \\
* 10^{-6} \mathrm{~kg} \mathrm{dL}^{-1}\end{array}$ & $\begin{array}{c}\text { Non-degraded } \\
\text { paper }\left(* 10^{-6} \mathrm{~kg}\right)\end{array}$ & Non-degraded paper $(\%)$ & $\begin{array}{c}\text { Degradation } \\
(\%)\end{array}$ \\
\hline 1 & 300.00 & B26 & 31.53 & 268.47 & 88.59 & 10.41 \\
\hline 2 & 300.00 & B38 & 29.98 & 270.02 & 89.11 & 9.89 \\
\hline 3 & 300.00 & B51 & 19.28 & 280.72 & 92.64 & 6.36 \\
\hline 4 & 300.00 & B6 & 19.08 & 280.92 & 92.71 & 6.29 \\
\hline 5 & 300.00 & B27 & 18.05 & 281.95 & 93.04 & 5.96 \\
\hline 6 & 300.00 & B64 & 17.82 & 282.18 & 93.12 & 5.88 \\
\hline 7 & 300.00 & $\mathrm{~B} 10$ & 16.73 & 283.27 & 93.48 & 5.52 \\
\hline 8 & 300.00 & B32 & 16.39 & 283.61 & 93.59 & 5.41 \\
\hline 9 & 300.00 & B47 & 14.99 & 285.01 & 94.05 & 4.95 \\
\hline 10 & 300.00 & B23 & 14.38 & 285.62 & 94.26 & 4.74 \\
\hline 11 & 300.00 & B18 & 14.09 & 285.91 & 94.35 & 4.65 \\
\hline 12 & 300.00 & B36 & 13.61 & 286.39 & 94.51 & 4.49 \\
\hline 13 & 300.00 & B13 & 13.45 & 286.55 & 94.56 & 4.44 \\
\hline 14 & 300.00 & B35 & 12.21 & 287.79 & 94.97 & 4.03 \\
\hline 15 & 300.00 & B17 & 11.92 & 288.08 & 95.07 & 3.93 \\
\hline 16 & 300.00 & B24 & 11.34 & 288.66 & 95.26 & 3.74 \\
\hline 17 & 300.00 & B22 & 11.22 & 288.78 & 95.30 & 3.70 \\
\hline 18 & 300.00 & B37 & 11.07 & 288.93 & 95.35 & 3.65 \\
\hline 19 & 300.00 & B37 & 11.07 & 288.93 & 95.35 & 3.65 \\
\hline 20 & 300.00 & B25 & 10.33 & 289.67 & 95.59 & 3.41 \\
\hline 21 & 300.00 & B20 & 0.24 & 299.76 & 98.92 & 0.08 \\
\hline
\end{tabular}

\subsection{Cellulolytic capacity of compatible consortia}

Figure $3 \mathrm{~A}$ and Figure 3B have shown the compatibility tests for bacteria and fungi performed in our laboratory. Supplementary Table 1 showed the combinations of bacterial and fungal strains without halo of inhibition and by which they became candidates to prepare a microbial consortium to degrade coffee pulp. In this test, the strains showing the highest production of glucose were confronted (Tables 1 and 2), of which the first 11 strains of bacteria and 12 strains of fungi were shown. These combinations were again evaluated in their cellulolytic capacity by measuring the level of glucose production by the glucose oxidase / peroxidase method (Table 3). Unlike fungi, the growth of all bacterial groups were evaluated. In the case of bacterial groups, the $8 \mathrm{CB}$ combination maintained a glucose level above $5^{*} 10^{-6} \mathrm{~kg} \mathrm{dL}{ }^{-1}$ at 30 days, and interestingly the $6 \mathrm{CB}$ and $7 \mathrm{CB}$ combinations remained almost constant at 30 days however, in all cases of combinations, glucose production was decreasing. In the case of fungus combinations, only the first 7 combinations were evaluated. Moreover, $1 \mathrm{CF}$ combination showed a gradual increase in glucose up to 30 days compared to the other combinations. Finally, 4CF combination maintained a high glucose production in the first 15 days $\left(11.3^{*} 10^{-6} \mathrm{~kg} \mathrm{dL}^{-1}\right)$.
Given all these results, the $8 \mathrm{CB}$ and $1 \mathrm{CF}$ consortia were selected to confront these microorganisms with coffee pulp waste.

Sowings were done separately from both fungi and bacteria, making 3 readings in the spectrophotometer at 15 , 28 and 42 days. Results of glucose production were obtained: for bacteria (Table 3), the sample that had the $5 \mathrm{CB}$ and $8 \mathrm{CB}$ consortia in the first 15 days, glucose production reached 14.7781 and $15.3859 * 10^{-6} \mathrm{~kg} \mathrm{dL}^{-1}$, respectively, which then decreased to 0.0433 and $5.044 * 10^{-6} \mathrm{~kg} \mathrm{dL}^{-1}$ respectively (Table $3)$. Therefore, consortium $8 \mathrm{CB}$ was selected.

The results obtained in this work were very similar to the trend reported by Mantilla and Pineda (2013), with a tendency to reduce production of reducing sugars at 42 days, which could be due to the specific bacterial enzymes on cellulose and hemicellulose no longer being active for the remaining bonds, which is why it manifests itself with a reduction in reducing sugars. Therefore, the greatest bacterial activity occurred after 15 days (Table 3 ) and the bacterial consortium with the best conditions is $8 \mathrm{~B}$. However, despite the variations observed with respect to the production of reducing sugars by the selected bacteria, ANOVA showed that there was a significant difference between glucose readings at different times $(\mathrm{p}=0.034, \mathrm{~F}=7.08)$. In contrast, for fungi this difference was not significant $(\mathrm{p}=0.8672, \mathrm{~F}=0.14$ ). 
Table 2: Glucose production by the selected fungal strains $\left({ }^{*} 10^{-6} \mathrm{~kg} \mathrm{dL}^{-1}\right)$.

\begin{tabular}{|c|c|c|c|c|c|c|}
\hline No & Wight paper $\left(* 10^{-6} \mathrm{~kg}\right)$ & Strain & $\begin{array}{l}\text { Glucose } \\
* 10^{-6} \mathrm{~kg} \mathrm{dL}^{-1}\end{array}$ & $\begin{array}{c}\text { Non-degraded } \\
\text { paper }\left({ }^{*} 10^{-6} \mathrm{~kg}\right)\end{array}$ & $\begin{array}{l}\text { Non-degraded } \\
\text { paper }(\%)\end{array}$ & $\begin{array}{c}\text { Degradation } \\
(\%)\end{array}$ \\
\hline 1 & 300.00 & F26 & 173.91 & 126.09 & 41.61 & 57.39 \\
\hline 2 & 300.00 & F15 & 106.43 & 193.57 & 63.88 & 35.12 \\
\hline 3 & 300.00 & $\mathrm{~F} 43$ & 23.17 & 276.83 & 91.36 & 7.64 \\
\hline 4 & 300.00 & F11 & 23.09 & 276.92 & 91.38 & 7.62 \\
\hline 5 & 300.00 & F14 & 22.68 & 277.32 & 91.52 & 7.48 \\
\hline 6 & 300.00 & $\mathrm{~F} 9{ }_{2}$ & 21.87 & 278.13 & 91.78 & 7.22 \\
\hline 7 & 300.00 & $\mathrm{~F} 14 a$ & 20.53 & 279.47 & 92.22 & 6.78 \\
\hline 8 & 300.00 & F51 & 20.21 & 279.79 & 92.33 & 6.67 \\
\hline 9 & 300.00 & $\mathrm{~F} 9_{1}$ & 19.89 & 280.11 & 92.44 & 6.56 \\
\hline 10 & 300.00 & F63 & 19.36 & 280.64 & 92.61 & 6.39 \\
\hline 11 & 300.00 & $\mathrm{~F} 25_{2}$ & 18.83 & 281.17 & 92.79 & 6.21 \\
\hline 12 & 300.00 & F6 & 18.79 & 281.21 & 92.80 & 6.20 \\
\hline 13 & 300.00 & F15 & 17.74 & 282.26 & 93.15 & 5.85 \\
\hline 14 & 300.00 & F6 & 17.58 & 282.42 & 93.20 & 5.80 \\
\hline 15 & 300.00 & F22 & 15.71 & 284.29 & 93.81 & 5.19 \\
\hline 16 & 300.00 & F31 & 15.47 & 284.53 & 93.89 & 5.11 \\
\hline 17 & 300.00 & $\mathrm{~F} 5_{1}$ & 15.19 & 284.81 & 93.99 & 5.01 \\
\hline 18 & 300.00 & $\mathrm{~F} 24$ & 12.47 & 287.53 & 94.88 & 4.12 \\
\hline 19 & 300.00 & $\mathrm{~F} 22_{2}$ & 0.12 & 299.88 & 98.96 & 0.04 \\
\hline
\end{tabular}

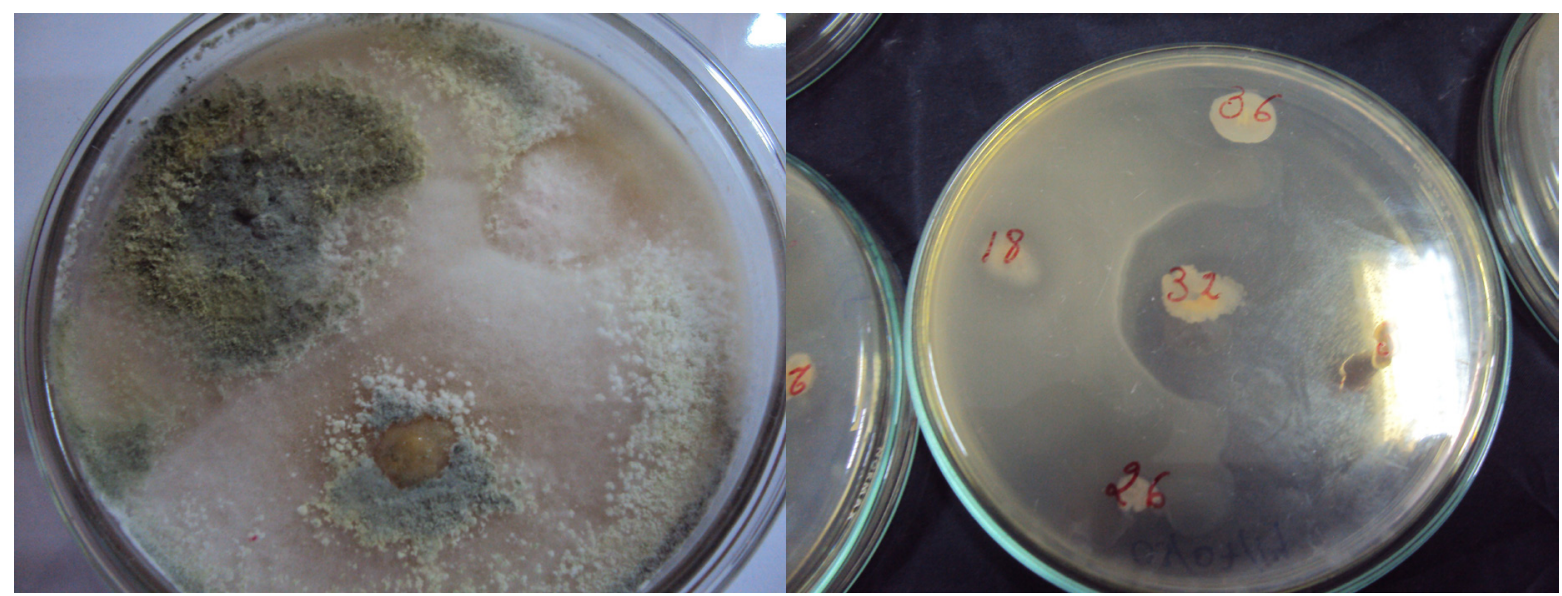

Figure 3: A: Fungi Colony showing their compatibility B. Bacteria colony showing their antagonism.

Table 3 has shown three moments of glucose production in the degradation of filter paper by the combinations of selected fungi, which has contrasted bacteria results.

On the one hand, the consortium of $1 \mathrm{H}$ strains in the first 15 days exhibited a production of $4.4448 * 10^{-6} \mathrm{~kg} \mathrm{dL}^{-1}$, which increased to $13.7288 \mathrm{mgdL}^{-1}$ after the time elapsed. In the third reading, production was standardized. On the other hand, the $4 \mathrm{H}$ consortium, which started with $11,283 * 10^{-6} \mathrm{~kg}$ $\mathrm{dL}^{-1}$, fell to $7,109 * 10^{-6} \mathrm{~kg} \mathrm{dL}^{-1}$. Therefore, the $1 \mathrm{H}$ consortium was chosen.
Zaldívar et al. (2001) found that Trichoderma viridae is one of the best cellulolytic fungi produces low activity of $\beta$-glucosidase, accumulating cellobiose and then inhibiting activity of the entire degraded complex (Zaldívar et al., 2001). Similar activity could have occurred in the present research. Consortia were found to increase first and then lower, whilst some other consortia did the opposite (Table 3), which may be due to less activity of the cellulolytic complex, due to the presence of some metabolite. An alternative hypothesis would be to see whether a statistical difference existed between the times, we found that, 
according to ANOVA, no significant difference existed $(\mathrm{p}>0.14)$. Therefore, degradation maybe occurring at a greater extent, only until the second sampling time in selected strains.

Due to the glucose production results shown in Table 3 , the best performing consortia were: Bacteria Consortium (8CB): B18, B26, B51, B10, B27, B64, B6, B38

Fungi Consortium (1CF): H14, H63, H92, H91, H51.

Table 3 Glucose production by selected consortia of bacterial and fungal strains having the filter paper as substrate.

\begin{tabular}{cccc}
\hline CODE & $\begin{array}{c}\text { Glucose Production } \\
\text { 1st read (15 days) }\end{array}$ & $\begin{array}{c}\left(* 10^{-6} \mathrm{~kg} \mathrm{dL}^{-1}\right) \\
2 \mathrm{nd} \mathrm{read}(25 \text { days })\end{array}$ & $\begin{array}{c}3 \mathrm{rd} \mathrm{read} \\
(30 \text { days })\end{array}$ \\
\hline $1 \mathrm{CB}$ & 5.0147 & 5.0305 & 2.1665 \\
$2 \mathrm{CB}$ & 2.1654 & 8.5748 & 2.6352 \\
$3 \mathrm{CB}$ & 5.5465 & 5.5641 & 0.5640 \\
$4 \mathrm{CB}$ & 6.1164 & 6.7455 & 0.1299 \\
$5 \mathrm{CB}$ & 14.7781 & 11.6414 & 0.0433 \\
$6 \mathrm{CB}$ & 5.8125 & 3.468 & 4.4604 \\
$7 \mathrm{CB}$ & 4.7108 & 3.4299 & 3.8546 \\
$8 \mathrm{CB}$ & 15.3859 & 8.0770 & 5.0440 \\
$9 \mathrm{CB}$ & 6.0784 & 5.2592 & 0.8229 \\
$10 \mathrm{CB}$ & 4.6348 & 6.4406 & 2.5553 \\
$1 \mathrm{CF}$ & 4.4448 & 13.6815 & 13.7288 \\
$2 \mathrm{CF}$ & 5.3566 & 5.9071 & 6.5546 \\
$3 \mathrm{CF}$ & 3.7990 & 4.8400 & 4.1089 \\
$4 \mathrm{CF}$ & 11.283 & 11.3100 & 7.1090 \\
$5 \mathrm{CF}$ & 4.6340 & 5.7546 & 3.5219 \\
$6 \mathrm{CF}$ & 7.6360 & 3.7729 & 5.4133 \\
$7 \mathrm{CF}$ & 4.5208 & 3.2012 & 5.1198 \\
\hline
\end{tabular}

\subsection{Preparation of microbial consortium for the degradation of coffee pulp at laboratory}

In order to evaluate the degradation capacity of coffee pulp for the $8 \mathrm{CB}$ and $1 \mathrm{HB}$ consortia selected above, a laboratory test was carried out inoculating in $10 \mathrm{~mL}$ volume. The set of strains of each microbial consortium were grown in plastic tanks to which $3 \mathrm{~kg}$ of coffee pulp were added and incubated at $24-28{ }^{\circ} \mathrm{C}$. The mix had a composition with proportion 4:1:1 (coffee pulp: guano islands: rok phosphate). The tests were done first to inoculate the bacterial consortium, followed after 7 days by the fungal consortium. In the second test the two consortia were inoculated simultaneously. As a control, coffee pulp containers were inoculated with only $0.010 \mathrm{~L}$ of distilled water. At 24 hours the foul odor was already produced by coffee pulp, which was higher in the first container with bacteria and fungi inoculated together. This evidenced an ongoing fermentation process of the microorganisms. In both vessels a degradation of $90 \%$ could be evidenced at 28 days, which confirmed the degradative capacity of both selected microbial consortia.

This degraded product was analyzed, finding concentrations of $3.47 \% \mathrm{~N}, 0.99 \% \mathrm{P}_{2} \mathrm{O}_{5}, 0.67 \% \mathrm{~K}_{2} \mathrm{O}$. As for the degradation time, this result was similar to that obtained by Vásquez de Díaz, Prada and Mondragon (2010) i.e. microorganisms that act on biodegradable matter degraded the pulp (in piles) in 40 days (Vásquez de Díaz; Prada; Mondragon, 2010). In natural conditions and without handling, this process normally takes 5 to 9 months, during which the degree of maturity is reached, when performing the biotransformation, mineralization or complete degradation of the coffee pulp.

\subsection{Characterization of the selected micro- organisms}

In order to know the microbial components, morphological and molecular characterization of the strains forming the consortium $8 \mathrm{CB}$ and $1 \mathrm{CH}$ was performed. Supplementary Table 2 shows the morphological characteristics and Table 4 the identification by sequencing the 16 s ribosomal gene:

\section{Bacteria: C B18, C B26, C B51, C B10, C B27, C B64, C B6, CB38 Fungi: $\mathrm{CF} 14, \mathrm{CF} 63, \mathrm{CF}_{2}, \mathrm{CF} 9_{1}, \mathrm{CH} 51$}

Table 4 shows the scientific names of the results of identification, missing identifying two colonies of bacteria (H92 and H14a) and one of fungus (B10).

Five strains of bacteria were characterized by biochemical identification tests such as Bacillus circulans and Bacillus cereus, and from the fungal strain bank nine strains were identified by characteristics compatible with the genera Trichoderma sp., Penicillium sp., Fusarium sp., Verticillium sp., Mucor sp. and Aspergillus sp. Here, bacterial strains have shown growth and formation of glucose.

\section{DISCUSSIONS}

\subsection{Isolation of cellulose degrading micro- organisms}

Silva and colleagues studied 80 isolated strains, of which 30 strains showed higher growth rate in malt agar medium and were evaluated for ligninas production. As an alternative hypothesis the proposed means for fungal isolation were PDA, malt agar, V8 agar, salt base agar and cellulose agar (Silva et al., 1990), which differed from the present work. Ferrer-Marcelo and colleagues used malt agar as a means of propagation and to obtain an abundant sporulation in cane bagasse fungi (Ferrer-Marcelo et al., 2011). Silva and 
colleagues also used this medium for the isolation, selection and characterization of ligninolytic fungi (Silva et al., 1990). Therefore, the results of fungi isolation of other authors support the results of this work.

Table 4 Summary of the identification of the selected strains that were part of consortia.

\begin{tabular}{|c|c|c|c|}
\hline Fungi & & Bacteria & \\
\hline Strain & Identiftcation* & Strain & Identiftcation* \\
\hline H14 & Fusarium sp. & B26 & $\begin{array}{c}\text { Ochrobactrum } \\
\text { pseudogrignonense }\end{array}$ \\
\hline $\mathrm{H}_{2}$ & No identified (Micelioestéril) & B38 & No identified \\
\hline $\mathrm{H} 14 a$ & No identified & B51 & Paenibacillus lautus \\
\hline H51 & Fusarium sp. & B6 & Bacillus xiamenensis \\
\hline $\mathrm{H} 9_{1}$ & Penicillum sp. & B27 & $\begin{array}{c}\text { Ochrobactrum } \\
\text { pseudogrignonense }\end{array}$ \\
\hline H63 & Cylindrocarpon sp. & B64 & $\begin{array}{c}\text { Ochrobactrum } \\
\text { pseudogrignonense }\end{array}$ \\
\hline & & B10 & No identified \\
\hline & & B18 & $\begin{array}{c}\text { Ochrobactrum } \\
\text { pseudogrignonense }\end{array}$ \\
\hline
\end{tabular}

(*) Only 5 strains of $1 \mathrm{CF}$ fungal consortium and only 6 strains of $8 \mathrm{CB}$ bacterial consortium were identified. Results of identification were done by specialized laboratories of UNALM, Lima, Peru.

Cedeño and colleagues used this agar medium in the isolation and selection of native bacteria (Bacillus similar to part of our results seen below) from Manabí-Ecuador with cellulolytic activity, having as a carbon source a cellulose obtaining 30 of 93 isolates equivalent to $32.3 \%$ with positive response (Cedeño et al., 2015). Also, in termites, Mantilla and Pineda found that the presence of halos in the solid culture medium with $\mathrm{CMC}$ was an indicator that the bacteria exhibited enzymes digesting cellulose, having isolated 9 bacteria from a total of 30 strains equivalent to $33.3 \%$ (Mantilla; Pineda, 2013). Both works differed from unlike the present work, in which 55 of 118 colonies were obtained equivalent to $46.6 \%$ with a higher positive response. The reason may be in the first case due to different Cedeño's conditions and in the second case they were isolated from termites where the bacterial number was much lower than what can be found in soil.

Although Ramírez and Coha isolated strains at $45{ }^{\circ} \mathrm{C}$ and $50{ }^{\circ} \mathrm{C}$ (Ramírez; Coha, 2013), Vásquez and colleagues used enzymatic degradation in an optimal range of activity between 30 and $40{ }^{\circ} \mathrm{C}$, and high thermal stability, and found that strain C. kusanoi L7 was good in degradation of lignin (Vázquez et al., 2019). Following this trend of lower temperature, in this work $25{ }^{\circ} \mathrm{C}$ produced both qualitative and quantitative results. Therefore, the present results are an extension of the previously reported works, and can even be carried out at an environmental temperature close to that found in equatorial countries and dependent on the season.

Extending the discussion of the isolation results to similar amount of fungal and bacterial strains were explored and discussed:

The use of coffee pulp for composting requires having at hand this set of microorganisms that efficiently and quickly degrade one of the main polluting products of the coffee beneficiary, e.g. Salazar, Acuña, De Salcedo (2009) and Duangjai et al. (2016).

Several studies of isolation of cellulose degrading microorganisms (Kausar, et al., 2010; Guerra; Florez; Rosero, 2015; Sahu et al., 2019), have shown differences in the number and capacity of microorganisms to degrade cellulose according to their original habitat. According to our results, there is a high number of fungal colonies isolated with the malt medium agar and V8 agar, while the nutrient agar medium favored the growth of a greater number of bacterial colonies using CMC as the only carbon source. Moreover, not all bacteria and fungi have the same cellulose degradation capability, whereby the isolates shown represent only colonies that generally showed greater degradation capacity, and thus were selected in order to better exploit their potential in a microbial consortium (Brossi et al., 2016). In addition, fungi appeared to predominate in the sampled soil, which may be due to the type of forest soil obtained where layers of decomposing organic waste, resulting from the fall of the phytomass of native trees under permanent shade, are well-known for fungi as the microbial dominant component (Carvajal; Valbuena; Rosero, 2012).

Other research supports our findings. For example, Ramirez and colleagues with native strains of Trichoderma reesei, Cladosporium herbarum and Aspergillus niger (to clarify, these are not seen later in Table 4) evaluated in vitro the cellulases produced in the presence of clear halos around of the colony when $5 \%$ congo red was added as a revealing agent, resulting in the recovery of 65 fungal colonies of the species studied (Ramírez; Bran; Uribe, 2012).

Similarly, Moreno and Vélez recommended the CongoCMC red-based method in screening for cellulolytic fungal bioprospecting as it was faster and produced a more sensitive response than DNS Moreno and Vélez (2011).

\subsection{Cellulolytic capacity of bacterial and fungi isolated}

Venegas and Suárez studied potential enzymes and microorganisms through a screening of cellulose and hemicellulose degradation found from 65 isolates. In result, 46 of them were able to grow in culture media containing $15 \% \mathrm{CMC}$ as the source of carbon substrate Venegas and Suárez (2004). On the other hand, in the present study at $1 \%$, 
in addition to xylan, oat flakes and apple pectin dissolved in mineral solution and agar.

The present results are related to those obtained by Zapata and Castellanos (2014). Zapata and Castellanos determined the enzymatic activity using pieces of Watman filter paper No. 1 in $50 \mathrm{mM}$ citrate buffer ( $\mathrm{pH} \mathrm{4.8)}$ as a substrate. The mixture of the reaction consisted of $0.005 \mathrm{~kg}$ of filter paper in $1 \mathrm{~mL}$ of citrate buffer $(50 \mathrm{mM}, \mathrm{pH} 4.8)$ and $50 \mu \mathrm{L}$ of the enzyme extract. These samples were incubated at $70{ }^{\circ} \mathrm{C}$ for 5 minutes, then $1 \% \mathrm{CMC}$ was added and incubated for 70 minutes having determined the amount of reducing sugars (Miller, 1959) and also citrate buffer at different $\mathrm{pH}$ (4.4 and 5.4) have worked at different temperatures $\left(50{ }^{\circ} \mathrm{C}\right.$ to $80{ }^{\circ} \mathrm{C}$ ) (Zapata and Castellanos, 2014). Further, selected 2 strains of Bacillus sp. potential for hydrolase production, which was observed in the present research in Table 4.

\subsection{Cellulolytic capacity of compatible consortia}

Bearing in mind the total times, Castillo-Guerra and colleagues determined the compatibility for growth between cellulolytic fungi, by preparing medium with CMC and placing growth fragments of two isolates in each one at a distance of $1 \mathrm{~cm}$ by incubating the culture media at $30{ }^{\circ} \mathrm{C}$ for two to three weeks and the growths no interference with a clear area between them labeled as incompatible Guerra, Florez and Rosero (2015). Complementing the above, Mantilla and Pineda found that the presence of halos in the solid culture medium with CMC was an indicator that bacteria have enzymes that digest cellulose. However, in their work they only isolated 9 bacteria from a total of 30 Mantilla and Pineda (2013). Castillo's results differed from this research, and this may be explained by have being isolated from termites where the bacterial number is much smaller than what can be found in soil.

Considering both times and varieties of fungi (Table 3), the present results extended previous work (Romano et al., 2013). On Romano research, bacteria native to Argentina were isolated, selected and the cellulolytic activity of three strains of native bacteria were evaluated. As a result, one strain was the only fungus whose enzymatic activity presented a tendency to increase to the maximum point for 7 days, and after 7 days more, its activity stabilized to cellulase degradation, increasing reducing sugars unlike soluble protein (Romano et al., 2013). These results were considered for the method of the present work, and one of the seven fungi was selected, since as time passed, the reducing sugars increased until standardized.

\subsection{Characterization of the selected micro- organisms}

Mantilla and Pineda have observed, from microscopic observation with Gram staining (the technique used in this work) Gram (-) bacilli of different curved and straight morphology in 9 types (Mantilla; Pineda, 2013). Therefore, the staining method and the characterization supported the results of this work with the characteristics of the 8 strains reported in Supplementary Table 2

This research found, through morpho-species analysis, filamentous saprophytic fungi of the Fusarium, Penicillum and Cylindrocarpon genera making the $1 \mathrm{CF}$ consortium. The genera Penicillum and Fusarium are widely distributed, e.g. Carrillo (2003) and Giri et al. (2005), and have been found in normal moorland (Gao et al, 2012), forests (Abarca; Mota, 2008), and monocultures (Samaniego-Gaxiola; ChewMadinaveitia, 2007). Moreover, because of their cellulolytic capacity against phytopathogenic nematodes, they have been tested as antagonists (Padilla et al., 2014). Although, current research such as sensors materials may overcome this finding (Sashidhar; Dubey; Kochar, 2019).

The use of fungi for coffee pulp degradation as done by previous research (Bhoite; Murthy, 2015) found that Penicillium verrucosum (isolated from the same coffee pulp) for the production of tannasa, has shown an $8-10 \%$ tannin content and this type of fungus has a degradation potential of $66.5 \pm$ $0.9 \%$ degradation of tannin. Other studies demonstrated the potential usability of the bacterium Bacillus sp. with a chemical decomposition capacity of coffee pulp, finding that the variation in cellulose was 0.126 to $0.115 \mathrm{~kg} \mathrm{~kg}^{-1} \mathrm{DM}$ with 0 and 28 days respectively (Ulloa; Verreth, 2002). Therefore, degrading capacity of fungi found in the CF1 consortium was corroborated (Table 3). However, the present results have also shown a synergistic activity for the degradation of coffee pulp used in laboratory conditions. Even more, due to antioxidant activity of tannin and others (Moreira et al., 2005) future work may consider to study the beneficial health properties and possibly to be tested in brain activity, such current work tested coffee as a co-factor (Córdova-Berríos; Mugruza-Vassallo; Flores-Benites, 2018) based on visual to temporal stimulus presentation (TorresTejeda et al., 2020) extending to augmented reality experiments as well as on attention (Mugruza-Vassallo; Potter, 2019) and multitasking (Mugruza-Vassallo et al., 2021).

\subsection{Final discussion}

According to previous research Vásquez de Díaz, Prada and Mondragon (2010), this process in natural and unmanaged conditions normally takes 5 to 9 months and within the ranges of research done decades ago Sánchez, Olguin and Mercado (1999). In addition, Ochrobactrum pseudo grignonense has recently been found in low concentration in dry coffee, Bressani (1978); De Bruyn et al. (2017) when this study found it in half of the identified bacteria (Table 4), constituting an extension of De Bruyn's work, bearing in mind humidity 2,3000 m.a.s.l. above and far from the sea. Moreover, Bacillus xiamenensis has been found spread to the pulp of coffee pulp, extending the research work Utekar and Deshmukh (2019). 
Additional work may lead to extending the study by Ulsido and $\mathrm{Li}$ (2016), they have found that the organic fertilizer of coffee pulp as a substrate for the growth of chickpeas (Cicer arietinum L.) in less time than other 3 treatments: soil Vegetable (Treatment I), topsoil + organic compost of animal manure (Treatment II), topsoil + organic compost of sawdust (Treatment III) (Ulsido; Li, 2016). However, Chong and Dumas (2012) tested with five physical granule fractions (500, $1,000,2,000,4,000$ and $8,000 \mathrm{pm}$ ) to determine the effect of particle size. They showed that smaller particles have higher rates of composting Chong and Dumas (2012). Therefore, combining different substrates and different physical granule fractions may lead to optimize composting.

Widjaja et al. (2019) studied the production of reducing sugar from coffee pulp residues by means of the biological pretreatment process in a fungi mixture culture between Aspergillus niger, Bacillus subtilis and Trichoderma reesei, followed by hydrolysis process using a mixture of pure cellulose and xylanase enzyme and using a varied mixture with fungal elements, which leads to extending the non-significant result of fungi Widjaja et al. (2019). In the present research, we obtained Fusarium sp. and Penicillum sp. found in common reports by Janissen and Huynh (2018) and Murthy and Naidu (2012) respectively. Moreover, a greater variety of species of bacteria from 545 increasing to 2400 m.a.s.l. was reported in high altitude agriculture with rainfall of at least $900 \mathrm{~mm}$ of annual rainfall (Siles; Margesin, 2016), and also recently have been explored in depth strain between 1800 and 2000 m.a.s.l. Junqueira et al. (2019) which confirms the facilitation of composting that we have found at 2300 m.a.s.l. in a cloud forest.

Finally, limitations of the present study were the compost was not solidified and tested. For example, currently works at the National University of Cajamarca with these consortia for the degradation of solid household residues for the production of organic fertilizers. Other works has been done using these bacterial microorganisms to evaluate their effect on the production of alcohol from tree residues that might be helpful to overcome some alcohol lack of production for COVID prevention.

\section{CONCLUSIONS}

An initial evaluation showed that more than $60 \%$ of the strains had a non-representative glucose production. However, these strains achieved the degradation of coffee pulp in Peru in 28 days.

Glucose production by the chosen fungal consortium (i.e. Fusarium sp., Penicillum sp., Cylindrocarpon sp.) was exponential, unlike the bacteria consortium (i.e. Ochrobactrum pseudo grignonense, Paenibacillus lauruscon and Bacillus xiamenensis) that reduced their activity over time, meaning that it is possible to minimize the period of degradation of coffee pulp using native microorganisms degraders, and freeing the environment from a great burden and making the production of organic fertilizer from coffee pulp profitable.

The organic fertilizer obtained from coffee pulp may be used for the installation phase of new coffee plantations, in nurseries, and as fertilizer for organic coffee production. Furthermore, the recovery and conservation of the ecosystem was expected, because the process did not generate waste since the pollutants are completely degraded. Therefore, the next step is to deepen the complete identification of the isolated microorganisms, as well as to carry out additional studies on their degradative activity with other organic wastes.

\section{FUNDING}

The authors thank the "Fondo de Investigación $y$ Desarrollo para la Competitividad (FIDECOM)" and NAJY CONSULTING \& BUSINESS SAC for the co-financing of the project, within the framework of which this research was conducted. Other funding that part-contributed to the completion of this work is being sponsored by UNTELS (Universidad Nacional Tecnológica de Lima Sur) under the research grants "Presentación Temporal de Realidad Aumentada para Telecomunicaciones" (see RCO-2422017-UNTELS) to further automatic visual recognition and "Concepción de Laboratorio de Electrofisiología Cognitiva: Electro Encefalo Grama (EEG) y realidad aumentada" (see RCO-229-2017-UNTELS) to a better research infrastructure and research duties provided for the corresponding author under "Decreto Supremo N.॰003-2018-MINEDU".

\section{ACKNOWLEDGEMENT}

The authors thank Lupe Pizán-Toscano from UNI (former Vice Chancellor at UNTELS) for encouraging multidisciplinary and inter-institutional research and also $\mathrm{S}$. Miñano-Suárez for this work.

\section{REFERENCES}

ABARCA, G. H.; MOTA. R. M. Hongos saprobios y endomicorrizógenos en suelos. Agroecosistemas cafetaleros de veracruz: Biodiversidad, manejoy conservación, Mexico, vol.193, 2008. 203p.

ALVINDIA, D. G.; ACDA, A. M. Mycoflora of coffee beans in the Philippines. International Society for Southeast Asian Agricultural Sciences, 16(2):116-125, 2013.

BARBOSA, R. J. F.; MEZA, C. L. S. Antagonismo in vitro de Trichoderma harzianum rifai sobre Fusarium oxysporum schlecht f. sp passiflorae en maracuy (Passiflora edulis Sims var. Flavicarpa) del municipio zona bananera Colombiana. Revista Facultad Nacional de Agronomía-Medellín, 62(1):4743-4748, 2009. 
BHOITE, R. N.; MURTHY, P. S. Biodegradation of coffee pulp tannin by Penicillium verrucosum for production of tannase, statistical optimization and its application. Food and Bioproducts Processing, 94:727-735, 2015.

BRESSANI, R. The by-products of coffee berries. In: BRAHAM, J. E.; BRESSANI, R. (Ed.). Coffee pulp- Composition, technology, and utilization. Ottawa, Canada: International Development Research Centre, p. 5-10, 1978.

BROSSI, M. J. et al. Soil-derived microbial consortia enriched with different plant biomass reveal distinct players acting in lignocellulose degradation. Microbial ecology, 71:616-627, 2016.

CÓRDOVA-BERRÍOS, L. L.; MUGRUZA-VASSALLO, C.; FLORES-BENITES, V. Missed signals in the congruency between visual distracting cues and auditory goals. In: Proceedings of the 8th International Conference on Information Communication and Management. New York NY United States: Association for Computing Machinery, p. 7-11, 2018.

DE BRUYN, F. et al. Exploring the impacts of postharvest processing on the microbiota and metabolite profiles during green coffee bean production. Applied and Environmental Microbiology, 83(1):2398-2414, 2017.

CALLE-VELEZ, H. Subproductos del café: Coffee by products. (Boletín Técnico No. 6) CENICAFE, 1977. 85p.

CARRILLO, L. Los hongos de los alimentos y forrajes. Argentina: Universidad Nacional de Salta, (Chapter 9), 2003. 98p.

CARVAJAL, J. E.; VALBUENA, J. O.; ROSERO, S. E. Evaluación in vitro de microorganismos nativos por su antagonismo contra moniliophthora roreri cif \& par en cacao (theobroma cacao 1.). Revista Facultad Nacional de Agronomía Medellín, 65(1):6305-6315, 2012.

CEDEÑO, M. G. et al. Aislamiento y selección de bacterias autóctonas de Manabí-Ecuador con actividad celulolítica. Cultivos Tropicales, 36(1):7-16, 2015.

CHONG, J. A.; DUMAS, J. A. Coffee pulp compost: Chemical properties and distribution of humic substances. The Journal of Agriculture of the University of Puerto Rico, 96(1-2):77-87 2012.

DIDANNA, H. L. A critical review on feed value of coffee waste for livestock feeding. World Journal of Biology and Biotechnology, 2:72-86, 2014.

DINIZ, I. C. et al. Degradation of sewage sludge compost disposed on the soil. Engenharia Agrícola, 36(5):822$829,2016$.
DUANGJAI, A. et al. Comparison of antioxidant, antimicrobial activities and chemical profiles of three coffee (Coffea arabica L.) pulp aqueous extracts. Integrative medicine research, 5(4):324-331, 2016.

FERRER-MARCELO, Y. et al. Selección de hongos aislados de bagazo de caña con actividad celulasa sobre celulosa cristalina para posibles aplicaciones industriales. ICIDCA, 45(1):3-12, 2011.

FRANÇA, L. et al. Seasonal and altitudinal changes of culturable bacterial and yeast diversity in alpine forest soils. Extremophiles, 20:855-873, 2016.

GAO, Z. et al. The production of $\beta$-glucosidases by Fusarium proliferatum NBRC109045 isolated from Vietnamese forest. AMB Express, 2(1):1-13, 2012.

GEREMU, M.; TOLA, Y. B.; SUALEH, A. Extraction and determination of total polyphenols and antioxidant capacity of red coffee (Coffea arabica L.) pulp of wet processing plants. Chem. Biol. Technol. Agric.3, 25, 2016.

GIRI, B. et al. Mycorrhizosphere: Strategies and functions. In: VARMA, A.; BUSCOT, F. Microorganisms in soils: Roles in genesis and functions. Springer: Berlin, Heidelberg, p. 213-252, 2005.

GUERRA, D. A.; FLOREZ, P. A.; ROSERO, S. E. Development and evaluation of an inoculum of cellulolytic fungi. Revista UDCA Actualidad \& Divulgación Científica, 18(1):217-226, 2015.

HECK, K. et al. Temperatura de degradação de residuos em processo de compostagem e qualidade microbiológica do composto final. Revista Brasileira de Engenharia Agricola e Ambiental, 17(1):54-59, 2013.

JANISSEN, B.; HUYNH, T. Chemical composition and value-adding applications of coffee industry by-products: A review. Resources, Conservation and Recycling, 128:110-117, 2018.

JUNQUEIRA, A. C. et al. First description of bacterial and fungal communities in Colombian coffee beans fermentation analysed using Illumina-based amplicon sequencing. Scientific Reports, 9:8794, 2019.

KASANA, R. C. et al. A rapid and easy method for the detection of microbial cellulases on agar plates using Gram's iodine. Current microbiology, 57:503-507, 2008.

KAUSAR, H. et al. Development of compatible lignocellulolytic fungal consortium for rapid composting of rice straw. International Biodeterioration \& Biodegradation, 64(7):594-600, 2010. 
MANTILLA, C. L.; PINEDA, R. C. Bacterias celulolíticas aisladas del intestino de termitas (Nasutitermes nigriceps) con características probióticas y potencial en la degradación del pasto. Revista Colombiana de Biotecnología, 15(1):8-16, 2013.

MAZZAFERA, P. Degradation of caffeine by microorganisms and potential use of decaffeinated coffee husk and pulp in animal feeding. Scientia Agricola, 59(4):815-821, 2002.

MILLER, G. L. Use of dinitrosalicylic acid reagent for determination of reducing sugar. Analytical Chemistry, 31(3):426-428, 1959.

MOREIRA D. P. et al. Contribution of chlorogenic acids to the iron-reducing activity of coffee beverages. Journal of Agricultural and Food Chemistry, 53(5):1399-1402, 2005.

MORENO, M. L.; VELEZ, D. U. Nuevo método para la cuantificación de la actividad endoglucanasa basado en el complejo celulosa-rojo congo. Orinoqua, 15(1):7-15, 2011.

MOROS, A. H. et al. Crecimiento de Macrophomina phaseolina y Fusarium oxysporum en medios de cultivo de harina de semillas de frijol Vigna unguiculata (L.) Walp., frijol chino Vigna radiata L. y quinchoncho Cajan uscajan (L.) millsp. Ciencia, 11(1):14-21, 2009.

MUGRUZA-VASSALLO, C.; POTTER, D. Context dependence signature, stimulus properties and stimulus probability as predictors of ERP amplitude variability. Frontiers in human neuroscience, 13:39, 2019.

MUGRUZA-VASSALLO, C. A. et al. Prior context influences motor brain areas in an auditory oddball task and prefrontal cortex multitasking modelling. Brain informatics, 8(1):1-28, 2021.

MURTHY, P. S.; NAIDU, M. M. Production and application of xylanase from Penicillium sp. utilizing coffee byproducts. Food Bioprocess Technol, 5:657-664, 2012.

NAYAK, V. et al. A comparative study of caffeine degradation by four different fungi. Bioremediation Journal, 17(2):79-85, 2013.

\section{INSTITUTO COLOMBIANO DE NORMAS TECNICAS} Y CERTIFICACION-INCOTEC. Norma Técnica Colombiana NTC 5167: Productos para la industria agrícola. Productos orgánicos usados como abonos o fertilizantes y enmiendas de suelo. 1, INCOTEC, Colombia, p.1-40, 2004

PADILLA, W. P.; ACEVES, M. O.; HERNANDEZ, A. E. Evaluación in vitro de hongos nematófagos en zonas arroceras de Costa Rica contra el nematodo agallador Meloidogyne javanica. Agronomía Costarricense, 38(2):19-32, 2014.
PARRA-GONZALEZ, E., CENTENO-BRICEÑO, S.; ARAQUE-CALDERON, Y. Actividad antifúngica de Burkholderia cepacia aislada de maíz amarillo (Zea mays L.) bajo diferentes condiciones de cultivo. Revista de la Sociedad Venezolana de Microbiología, 29:103-109, 2009.

RAMÍREZ, L. A. G.; BRAN, J. A. P.; URIBE, M. A. Evaluación in vitro de celulasas producidas por cepas nativas de Trichoderma reesei, Cladosporium herbarum y Aspergillus niger. Journal of Agriculture and Animal Sciences, 1(1):1-9, 2012.

RAMÍREZ, P.; COHA, J. M. Degradación enzimática de celulosa por actinomicetos termófilos: Aislamiento, caracterización y determinación de la actividad celulolítica. Revista Peruana de Biología, 10(1):67$77,2013$.

RAPHAEL, K.; VELMOUROUGANE, K. Vermicomposting of coffee processing wastes using exotic (Eudrilus Eugeniae) and native earthworm (Perionyxcey lanesis) species. Macromolecular Symposia, 320(1):61-69, 2012.

ROMANO, N. et al. Characterization of cellulolytic activities of environmental bacterial consortia from an Argentinian native forest. Current microbiology, 67(2):.138-147, 2013.

SAHU, A. et al. Thermophilic ligno-cellulolytic fungi: The future of efficient and rapid bio-waste management. Journal of environmental management, 244:144-153, 2019.

SAJITH, S. et al. Production and partial purification of cellulase from a novel fungus, Aspergillus flavus BS1. Annals of Microbiology, 64:763-771, 2014.

SALAZAR, A. N.; ACUÑA, R. S.; DE SALCEDO, M. G. Composición química de la pulpa de café a diferentes tiempos de ensilaje para su uso potencial en la alimentación animal. Zootecnia Tropical, 27(2):135-141, 2009.

SAMANIEGO-GAXIOLA, J. A.; CHEW-MADINAVEITIA, Y. Diversidad de géneros de hongos del suelo en tres campos con diferente condición agrícola en La Laguna. Revista Mexicana de Biodiversidad, 78(2):383-390, 2007.

SÁNCHEZ, G.; OLGUIN, E. J.; MERCADO, G. Accelerated coffee pulp composting. Biodegradation, 10:35-41, 1999.

SASHIDHAR, P.; DUBEY, M. K.; KOCHAR, M. Sensing soil microbes and interactions: How can nanomaterials help?. In: PRASAD, R. (eds). Microbial nanobionics. Nanotechnology in the Life Sciences. Springer: Cham, p. 213-236, 2019. 
SAZCI, A.; ERENLER, K.; RADFORD, A. Detection of cellulolytic fungi by using Congo red as an indicator: A comparative study with the dinitrosalicyclic acid reagent method. Journal of Applied Bacteriology, 61(6):559$562,1986$.

SCHWIMMER, S.; KURTZMAN, R. H.; HEFTMANN, E. Caffeine metabolism by Penicillium roqueforti. Archives of biochemistry and biophysics, 147(1):109-113, 1971.

SERNA-JIMENEZ, J. A. et al. Aprovechamiento de la pulpa de café como alternativa de valorización de subproductos. Revista Ion, 31(1):37-42, 2018.

SHOKRKAR, H.; EBRAHIMI, S.; ZAMANI, M. A review of bioreactor technology used for enzymatic hydrolysis of cellulosic materials. Cellulose, 25(11):6279-6304, 2018.

SILES, J. A.; MARGESIN, R. Abundance and diversity of bacterial, archaeal, and fungal communities along an altitudinal gradient in alpine forest soils: What are the driving factors. Microbial Ecology, 72:207-220, 2016.

SILES, J. A.; MARGESIN, R. Seasonal soil microbial responses are limited to changes in functionality at two Alpine forest sites differing in altitude and vegetation. Scientific Reports, 7:2204-2204, 2017.

SILVA, H.; LANDA, A.; AGOSIN, E. Aislamiento, selección y caracterización de hongos ligninoliticos chilenos.

Archivos de biología y medicina experimentales, 23:4149, 1990.

TORRES-TEJEDA, S. et al. Variations of reaction times explained by stimuli changes in size and perspective in 2D and 3D for selective attention. Revista Mexicana de Ingeniería Biomédica, 41(1):91-104, 2020.

ULLOA, R. J.; VERRETH, J. A. Growth, feed utilization and nutrient digestibility in tilapia fingerlings (Oreochromis aureus Steindachner) fed diets containing bacteria-treated coffee pulp. Aquaculture Research, 33(3):189-195, 2002.

ULSIDO, M. D.; LI, M. Effect of organic matter from coffee pulp compost on yield response of chickpeas (Cicer arietinum L.) in Ethiopia. Engineering for Rural Development, (15):1339-1347, 2016.

UTEKAR, G. V.; DESHMUKH, H. V. Characterization of Bacillus sps from gut flora of earthworm Eudrillus eugeniae feed on sugar industry waste. Research Journal of Life Sciences, 5(2):887-895, 2019.
VÁSQUEZ DE DIAZ, M. C.; PRADA, P. A.; MONDRAGON, M. A. Optimización del proceso de compostaje de productos post-cosecha (cereza) del café con la aplicación de microorganismos nativos. Nova, 8(14):214-219, 2010.

VÁZQUEZ, M. A. et al. Cellulolytic and ligninolytic potential of new strains of fungi for the conversion of fibrous substrates. Biotechnology Research and Innovation, 3(1):177-186, 2019.

VENEGAS, J. F.; SUAREZ, D. E. Screening para el aislamiento y caracterización de microorganismos y enzimas potencialmente útiles para la degradación de celulosas y hemicelulosas. Revista Colombiana de Biotecnología, 6(1):58-71, 2004.

VELASQUEZ, S. et al. Classification of the maturity stage of coffee cherries using comparative feature and machine learning. Coffee Science, 16:e161710, 2021.

VIEGAS, C. et al. Fungal contamination in green coffee beans samples: A public health concern. Journal of Toxicology and Environmental Health, 80:719-728, 2017.

VRDOLJAK, G. et al. Characterization of a diesel sludge microbial consortia for bioremediation. Scanning, 27(1):8-14, 2005.

WANG, C. M. et al. Characterization of a novel thermophilic, cellulose-degrading bacterium Paenibacillus sp. strain B39. Letters in applied microbiology, 47(1):46-53, 2008.

WIDJAJA, T. et al. Production of reducing sugar from coffee pulp waste using mixture of microorganisms, enzymes, and surfactants. IOP Conference Series: Materials Science and Engineering, 543:012003, 2019.

ZALDÍVAR, M. et al. Trichoderma aureoviride 7-121, a mutant with enhanced production of lytic enzymes: its potential use in waste cellulose degradation and/ or biocontrol. Electronic Journal of Biotechnology, 4(3):13-14, 2001.

ZAMBRANO-FRANCO, D. A.; ISAZA-HINESTROZA, J. D. Demanda química de oxígeno y nitrógeno total, de los subproductos del proceso tradicional de beneficio húmedo del café. Cenicafé, 49(4):279-289, 1998.

ZAPATA, H. B. M.; CASTELLANOS, R. C. Aislamiento e identificación de bacterias celulolíticas termófilos de géiseres naturales de candarave - TACNA. Ciencia en Desarrollo, (18):29-36, 2014. 